\title{
Brazilian fiscal institutions: the Cardoso reforms, 1995-2002
}

\author{
Fabio Giambiagi and Marcio Ronci
}

$\mathrm{T}$

his paper looks at Brazil's fiscal policy during the two administrations of President Fernando Henrique Cardoso: 1995-1998 and 1998-2002. It stresses that the authorities' austere attitude was as important as institutional and structural reform for the fiscal adjustment that followed the 1998-1999 crisis. The principal cause of the fiscal deterioration in 1995-1998 was the reduction in the primary balance rather than the increase in the interest burden, while the fiscal adjustment in 1999-2002 was largely due to increased revenues, as primary public expenditure by the federal government continued to grow in real terms. We consider the outlook for fiscal sustainability and conclude that, to preserve the country's hard-won fiscal discipline, the austere fiscal attitude shown recently by the authorities should be permanently embedded into fiscal institutions.

Fabio Giambiagi

Researcher at the Institute of Applied Economic Research (IPEA), Ministry of Planning, Brazil

$\bullet$ fgiambia@ipea.gov.br

Marcio Ronci

Senior Economist

International Monetary Fund (IMF)

- mronci@imf.org 


\section{I}

\section{Introduction}

Following the Collor Plan (1990), the average publicsector primary balance recorded a surplus of $2.9 \%$ between 1991 and 1994. In contrast, following the Real Plan (June 1994), ${ }^{1}$ this balance underwent a dramatic deterioration, averaging a deficit of $0.2 \%$ of GDP during 1995-1998. During those years, the authorities' rhetoric favoured fiscal austerity, but unrelenting pressure to increase expenditures more than offset increases in revenues or cuts in other spending items. Proposals to set public-sector deficit ceilings simply failed to generate broad support.

At the end of 1998, Brazil faced a deep external and fiscal crisis and signed a Stand-By Arrangement with the International Monetary Fund (IMF) for 19992001. Following the sharp exchange-rate devaluation of January 1999 the agreement was reassessed, and in 2001 it was extended until the end of 2002. In this context, there was a major policy regime change and during 1999-2002 the public sector recorded an average primary surplus of an unprecedented $3.6 \%$ of GDP. $^{2}$ During the second Cardoso term, the public sector was clearly operating under a hard budgetary constraint in the form of a floor for the consolidated primary surplus, implementation of which meant a major institutional change in the management of the Brazilian public finances. ${ }^{3}$

Although day-to-day fiscal policy continued to be based on floors for the primary surplus rather than

This paper is a shortened version of Giambiagi and Ronci (2004), and it has benefited from comments by Max Alier, Fabio Barbosa, Nigel Chalk, Martin Gilman, Vincent Moissinac, Laura Papi, Murilo Portugal, Hemant Shah and Evan Tanner. The views expressed in this paper are those of the authors and do not necessarily represent those of the International Monetary Fund (IMF) or the Brazilian government.

${ }^{1}$ The year 1990 is usually disregarded in analyses of Brazilian fiscal policy in the 1980s and 1990s, as it was the first year of the Collor Plan and is considered atypical due to the extraordinary revenues collected.

2 In this paper, the concept of the public-sector borrowing requirement (PSBR) refers to the nominal rather than to the operational result, except where otherwise specified.

3 For our purposes, fiscal institutions include both the legal framework of fiscal policy and the authorities' fiscal attitude, as enforcement of formal rules depends on this. It is important to emphasize that institutional arrangements are not primarily to be understood as formal organizations and written laws and regulations. Institutions are the rules of the game - formal or informal rulesthat are used by societal actors (North, 1990). ceilings for the nominal deficit, in effect increases in financial expenditure had a direct effect on the primary target. This was apparent in the authorities' efforts to ensure that the nominal deficit did not exceed certain limits, corresponding essentially to a regime of deficit targeting. For example, the increase in interest rates during 2001 and its impact on the projection of higher interest payments in 2002 led the authorities to raise the primary surplus target for 2002 . The original official target for the year of $2.7 \%$ of GDP was raised to $3.9 \%$ of GDP precisely in order to make up for the higher interest burden. ${ }^{4}$

This article provides a detailed account of publicsector finance trends during the two administrations of President Fernando Henrique Cardoso: 1995-1998 and 1999-2002. ${ }^{5} \mathrm{We}$ argue that the change in the authorities' attitude to fiscal policy in the context of the 1998-1999 balance-of-payments crisis was as important as the legal and constitutional changes approved at the end of the first and beginning of the second Cardoso administrations to bring about the primary balance shift to $3.7 \%$ of GDP between 1995 1998 and 1999-2002. Only President Castelo Branco's reforms (1964-1967) can be compared in scope to President Cardoso's, and the latter were implemented under much more difficult political circumstances. ${ }^{6}$

Two important messages come out of our account. First, the principal cause of the fiscal deterioration in the first Cardoso administration was the deterioration in the primary balance rather than the increase in the interest payment burden. Second, the fiscal adjustment in the second Cardoso administration was to a large

\footnotetext{
${ }^{4}$ The original primary surplus target of $2.7 \%$ of GDP for 2002 had been announced in 2000 , in the context of a significant fall in interest rates, which, as was foreseen at the time, would continue in subsequent years. After this, however, the nominal Special System of Clearance and Custody (SELIC) rate, which fell to $15 \%$ at the start of 2001 , rose to more than $20 \%$ during 2002, making it necessary to revise the projected numbers for the following year.

${ }^{5}$ While the data for this study begin in 1994, for reasons of space we focus mainly on the fiscal adjustment that took place after 1998 . For an account of the various aspects of fiscal policy during the 1995-1998 period, see Além and Giambiagi (1999). For the period before the Real Plan in 1994, see Giambiagi (1997).

${ }^{6}$ For an account of Castelo Branco's reforms, see Barbosa, Salazar and de Faro (1989) and Skidmore (1988).
} 
extent due to increased revenues, while primary federal public expenditure rose in real terms during the eight years of the two administrations. These aspects of Cardoso's fiscal adjustment underline the need to preserve hard-won fiscal discipline and improve the adjustment over the coming years. Key to achieving fiscal sustainability has been the austere fiscal stance of the recent authorities, which should be permanently embedded in fiscal institutions.

The article is divided into seven sections. After this brief introduction, section II reviews the evolution of the public-sector borrowing requirement (PSBR) during 1995-2002. Section III highlights the major factors and structural reforms underlying the fiscal adjustment since 1999. Section IV deals with temporary revenue sources since the mid-1990s. Section V describes the evolution of the public-sector debt. Section VI demonstrates the importance of the change in the authorities' attitude to fiscal policy. Lastly, section VII presents a summary and conclusions. The appendix provides empirical evidence on public debt sustainability during 1995-2002.

\section{II}

\section{Overview of the public-sector borrowing requirement, 1995-2002}

The performance of the public-sector finances since the Real Plan (1994) can be divided into two periods: 1995 to 1998 and 1999 to 2002, each corresponding to one of President Cardoso's terms. There were two major turning points in the policy regime: the first in 1995, when the significant primary balance surpluses achieved in previous years were rapidly eroded, and the second in 1999, when a strong fiscal adjustment was carried out at all levels of government (table 1).

With regard to the major aggregates, four facts stand out: ${ }^{7}$

First, until 1998 the federal government recorded a progressive deterioration in its nominal deficit, partly because it "inherited" debts from individual states, which in effect represented a "socialization" of losses, and partly because tight monetary policy had a greater impact on its financing costs. As a result, the federal government's nominal borrowing requirements

\footnotetext{
${ }^{7}$ Comparing the fiscal outcomes of the first Cardoso administration with those of the year of the Real Plan (1994) is problematic as 1994 was a relatively atypical year. The primary surplus of $5.4 \%$ of GDP recorded then was well above the average of $2.2 \%$ of GDP in the three preceding years. This is largely explained by the fact that in 1994 tax revenues benefited both from the end of inflationary erosion and from the economic boom in the first six months of the plan, while public spending lagged behind. On the other hand, in 1994 the "above the line" primary surplus published by the federal government was almost $1 \%$ of GDP below the figure published by the Central Bank (which is the official figure), leading us to believe that there may have been a methodological problem in determining the primary balance, so that this may have been overestimated to some extent. For these reasons, we chose to compare period averages.
}

increased from a third of the total PSBR in 1995 to two thirds in 1998.

Second, compared with 1991-1994, all three levels of government showed the same primary balance deterioration in 1995-1998, followed by a marked improvement in 1999-2002 (table 2).

Third, interest payments averaged $7 \%$ of GDP throughout 1995-2002, contributing a great deal to the high average nominal deficit of $5.5 \%$ of GDP during the same period. Although total public debt was relatively low during the first years of the Real Plan, interest payments were high as real interest rates came under severe pressure, partly because of the risk of lending to the government in an environment of growing fiscal deterioration, and partly because of the need to attract external financing to pay for external current-account deficits following the Asian and Russian crises. ${ }^{8}$ Using the extended national consumer price index (IPCA) as a deflator, the Special System of Clearance and Custody (SELIC) gross real interest rate averaged 22\% during 1995-1998. Subsequently, it declined to an average of $10 \%$ during 1999-2002. However, this lower rate applied to a much higher public-sector debt and, in combination with the effects of currency devaluation, resulted in continued large interest payments (figure 1). ${ }^{9}$

\footnotetext{
${ }^{8}$ see Ferreira and Tulio (2002), p.153.

${ }^{9}$ See Garcia and Didier (2000) for an analysis of the determinants of interest rates in Brazil.
} 
TABLE 1

Brazil: Public-sector borrowing requirement

$(\text { Percentages of GDP })^{a}$

\begin{tabular}{|c|c|c|c|c|c|c|c|c|c|}
\hline & 1994 & 1995 & 1996 & 1997 & 1998 & 1999 & 2000 & 2001 & 2002 \\
\hline \multicolumn{10}{|l|}{ Public-sector borrowing } \\
\hline requirement & -27.0 & -7.3 & -5.9 & -6.1 & -7.5 & -5.8 & -3.6 & -3.6 & -4.6 \\
\hline Federal government & -10.2 & -2.4 & -2.6 & -2.6 & -4.9 & -2.7 & -2.3 & -2.1 & -0.8 \\
\hline States and municipalities & -12.1 & -3.6 & -2.7 & -3.0 & -2.0 & -3.1 & -2.1 & -2.0 & -3.8 \\
\hline Public-sector enterprises & 4.7 & 1.3 & 0.6 & 0.4 & 0.5 & -0.1 & -0.7 & -0.6 & 0.0 \\
\hline Primary balance & 5.2 & 0.3 & -0.1 & -1.0 & 0.0 & 3.2 & 3.5 & 3.6 & 3.9 \\
\hline Federal government & 3.3 & 0.5 & 0.4 & -0.3 & 0.6 & 2.3 & 1.9 & 1.8 & 2.4 \\
\hline Federal government and Central Bank & 3.1 & 0.5 & 0.5 & 0.0 & 1.3 & 3.3 & 2.8 & 2.9 & 3.6 \\
\hline Social security ${ }^{b}$ & 0.2 & 0.0 & -0.1 & -0.3 & -0.8 & -1.0 & -0.9 & -1.1 & -1.3 \\
\hline States and municipalities & 0.8 & -0.2 & -0.5 & -0.7 & -0.2 & 0.2 & 0.5 & 0.9 & 0.8 \\
\hline Public-sector enterprises & 1.2 & -0.1 & 0.1 & 0.1 & -0.4 & 0.7 & 1.1 & 0.9 & 0.7 \\
\hline Interest payments & -32.2 & -7.5 & -5.8 & -5.1 & -7.5 & -9.0 & -7.1 & -7.2 & -8.5 \\
\hline Federal government & -13.4 & -2.9 & -2.9 & -2.3 & -5.5 & -5.0 & -4.1 & -3.9 & -3.1 \\
\hline States and municipalities & -12.8 & -3.4 & -2.2 & -2.3 & -1.8 & -3.4 & -2.6 & -2.9 & -4.6 \\
\hline Public-sector enterprises & -5.9 & -1.3 & -0.7 & -0.5 & -0.2 & -0.6 & -0.3 & -0.4 & -0.7 \\
\hline \multicolumn{10}{|l|}{ Memorandum items } \\
\hline Balance sheet adjustment (flows) & $\ldots$ & $\ldots$ & -1.9 & 1.8 & -1.0 & -6.9 & 0.1 & -3.9 & -7.6 \\
\hline Privatization & $\cdots$ & $\cdots$ & 0.1 & 1.9 & 1.3 & 0.5 & 1.4 & -0.4 & -0.8 \\
\hline Other & $\begin{array}{l}\cdots \\
\cdots\end{array}$ & $\begin{array}{l}\cdots \\
\cdots\end{array}$ & -2.0 & -0.1 & -2.3 & -7.4 & -1.3 & -3.5 & -6.8 \\
\hline Domestic debt adjustment & $\cdots$ & $\cdots$ & 0.0 & 0.0 & -0.4 & -3.8 & -0.4 & -1.4 & -3.6 \\
\hline External debt adjustment & $\ldots$ & $\ldots$ & -0.1 & -0.1 & -0.3 & -2.7 & -0.6 & -0.6 & -3.6 \\
\hline Other adjustments & $\begin{array}{l}\cdots \\
\cdots\end{array}$ & $\begin{array}{l}\cdots \\
\cdots\end{array}$ & -1.9 & 0.0 & -1.6 & -0.9 & -0.3 & -1.5 & 0.4 \\
\hline
\end{tabular}

Source: Central Bank of Brazil.

a The minus sign indicates a deficit.

b Social security revenues less benefit payments.

TABLE 2

Brazil: Public-sector primary balance

(Period averages as percentages of GDP $)^{a}$

\begin{tabular}{lccc}
\hline & $1991-1994$ & $1995-1998$ & $1999-2002$ \\
\hline Primary balance & 2.9 & -0.2 & 3.6 \\
Federal government & 1.6 & 0.3 & 2.1 \\
Federal government and Central Bank & 1.0 & 0.6 & 3.2 \\
Social security & 0.6 & -0.3 & -1.1 \\
States and municipalities & 0.7 & -0.4 & 0.6 \\
Public-sector enterprises & 0.7 & -0.1 & 0.9 \\
Federal & 1.1 & 0.2 & 0.7 \\
State and municipal & -0.4 & -0.3 & 0.2 \\
\hline
\end{tabular}

Source: Central Bank of Brazil.

a The minus sign indicates a deficit.

b Social security revenues less benefit payments.

Fourth, there was the emergence in the fiscal accounts of a variable that would become crucial for the dynamics of the public-sector debt: the "balance sheet adjustment", which dates back to the period

${ }^{10}$ Strictly speaking, the recognition of previously unrecorded old debts as a balance sheet adjustment began with the Collor
1995-1998. ${ }^{10}$ This variable involves "below the line" factors that do not affect PSBR flows but that modify the value of the public-sector debt. Privatizations

administration with the "resetting" of obligations through the socalled "privatization currencies", i.e., debts that were accepted as a means of payment in the sale of State-owned companies. 
FIGURE 1

Brazil: Interest payments and real interest rate

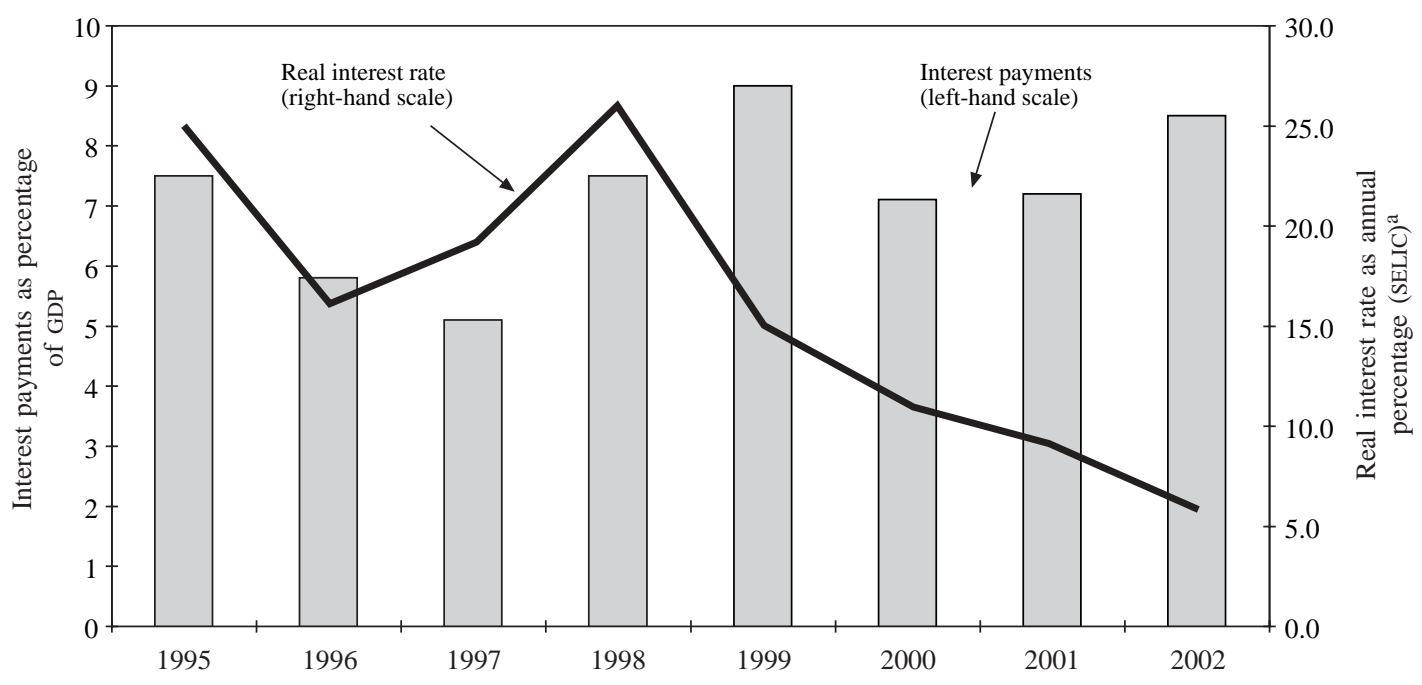

Source: Central Bank of Brazil.

a SELIC: Special System of Clearance and Custody.

reduce public debt, while recognizing previously unrecorded debts and revaluing public debt denominated in foreign currency due to exchange-rate devaluations increase it. In net terms, these effects generated a cumulative change in the public-sector debt of 19 percentage points of GDP between 1994 and 2002.

\section{III}

\section{Fiscal adjustment and reforms}

As we explained in the previous section, interest payments did not account for the decline in the nominal deficit, because they remained high throughout the 1995-2002 period. We shall now turn our attention to the causes of the fiscal adjustment since 1999, focusing on the primary balance results, which exclude interest payments. At the federal level there was a significant increase in tax revenues, while non-financial expenditure grew continuously. At state and municipal levels, structural and institutional changes led to a gradual improvement of the primary balance after 1998. Public-sector enterprises' primary balances have also improved greatly since 1999 , mainly due to the results of the State oil company (Petrobras).

Both during the first Cardoso administration and, in particular, during the second one, a number of important structural and institutional reforms were carried out in five areas: the fiscal regime of states and municipalities; privatization of public-sector enterprises; social security; the financial system, and budget procedures (box 1). These reforms were closely associated with the authorities' ability to carry out the fiscal adjustment in 1999-2002.

\section{The federal government}

Table 3 shows the revenue and expenditure breakdown of the federal government primary balance from 1994 to 2002, based on data published by the Ministry of Finance. ${ }^{11}$ Two trends stand out:

\footnotetext{
${ }^{11}$ The data refer to the "above the line" statistics calculated by the Brazilian Treasury, which also cover the Social Security and Central Bank balances. The difference between that figure and the "below the line" primary balance published by the Central Bank, calculated as borrowing requirements minus nominal interest, is adjusted for a "statistical discrepancy" akin to the errors and omissions statistic in the balance of payments.
} 
Box 1

CARDOSO'S FISCAL REFORMS

The fiscal regime of states and municipalities

There was without doubt a genuine change in the fiscal regime of states and municipalities, characterized by the removal of various sources of structural fiscal imbalances. Among the changes observed, we note:

- the privatization of the majority of banks owned by state governments, closing off a financing source for state treasuries;

— rigid restrictions on the practice of providing advances on budgetary resources, which was effectively a mechanism for borrowing from the financial system;

- the blocking of mechanisms for issuing judicial credits (precatórios), i.e., securities for the payment of judicial settlements with the private sector, which were often used in practice for other purposes and contributed to the fiscal deterioration of state governments during part of the 1990s;

- the refinancing of state and municipal debts through the federalization of debt securities issued by state and municipal governments in return for collateralization of their future revenues. This measure prompted state governments to make fiscal adjustments to repay their debt over a 30-year period (subject to a ceiling of $30 \%$ of revenues in most cases), under penalty of the federal government using its legal powers to withhold constitutional transfers and even appropriate part of the revenues from the state sales tax on merchandise and services (ICMS);

- among other things, the Fiscal Responsibility Act (Lei de Responsabilidade Fiscal, supplementary law No. 101 of 4 May 2000) provided for ceilings on payroll expenses in relation to the total revenues of the state and federal governments, restricted the authorities' powers (particularly in election years), introduced transparency rules for reporting public-sector accounts, and prohibited new refinancing of state and municipal debt by the federal government.

The privatization of public-sector enterprises

Privatization also represented a significant structural change. It removed what had previously been a potential source of pressure on public-sector spending, associated with the investments of public-sector companies. Had these returned to the high levels of investment of the early 1980s, they would have put considerable pressure on the public debt. At the same time, the sale of a number of traditionally loss-making public enterprises such as the federal railway company eliminated what had been a permanent source of pressure on the public-sector accounts. With regard to individual state governments, not only did these rid themselves of several loss-making companies, but the discipline of preparing these companies for privatization in itself brought about a significant improvement in the management of the remaining state-owned companies.

\section{Social security}

The constitutional amendment to the social security scheme, approved in 1998, permitted:

— the introduction of a minimum retirement age for public-sector employees, and a progressive increase in the retirement age for employees with shorter lengths of service;

- the hiring of new public employees under the general social security regime, without the privileges of the public-sector employee pension regime, and the setting up of pension funds for new public employees;

- removal from the federal constitution of the formula for calculating pension benefits, thereby making it possible to enact legislation for this purpose. This was done during 1999-2002 with the passing of a law on the "social welfare factor"; a this helped to contain the social security deficit, as the new formula for calculating pension benefits discouraged early retirement and the underreporting of income.

The financial system

By strengthening the financial system, the reforms addressed potential sources of deficits. The reforms included:

- approval of the Incentive Programme for the Restructuring and Strengthening of the National Financial System (PROER);

- privatization of various state banks, in a number of cases following federalization, thereby ending what had been one of the main sources of fiscal imbalances during the 1980s and 1990s;

- opening up the financial sector further to foreign capital, with the sale of a number of banks to multinational banking groups, thereby increasing competition within the banking system; 
— the requirement by the Central Bank that banks adopt more rigid lending criteria, leading to a substantial improvement in the health of the system and reducing its exposure to risk;

- the strengthening of federally owned banks through capitalization, provisions for non-performing loans, and compliance with the Basel guidelines.

\section{Budget procedures}

The Fiscal Responsibility Act also changed the budget procedures for the Budget Guidelines Act (Ley de Diretrizes Orçamentárias), which is approved by Congress by June of each year and sets the parameters for the next year's general federal budget, submitted to Congress in August. The Fiscal Responsibility Act stipulated that the Budget Guidelines Act should include not only the federal government's primary result target for the general federal budget, but also the targets for the following two years. This embryonic medium-term budget framework has provided an effective form of budgetary constraint: it limits total expenditure and attempts to make additional expenditure conditional on the resources available. The medium-term budget is a genuine institutional innovation in Brazil, where budgetary restrictions have traditionally been circumvented.

a See Ornelas and Vieira (1999).

TABLE 3

Brazil: Government primary balance

$(\text { Percentages of GDP })^{a}$

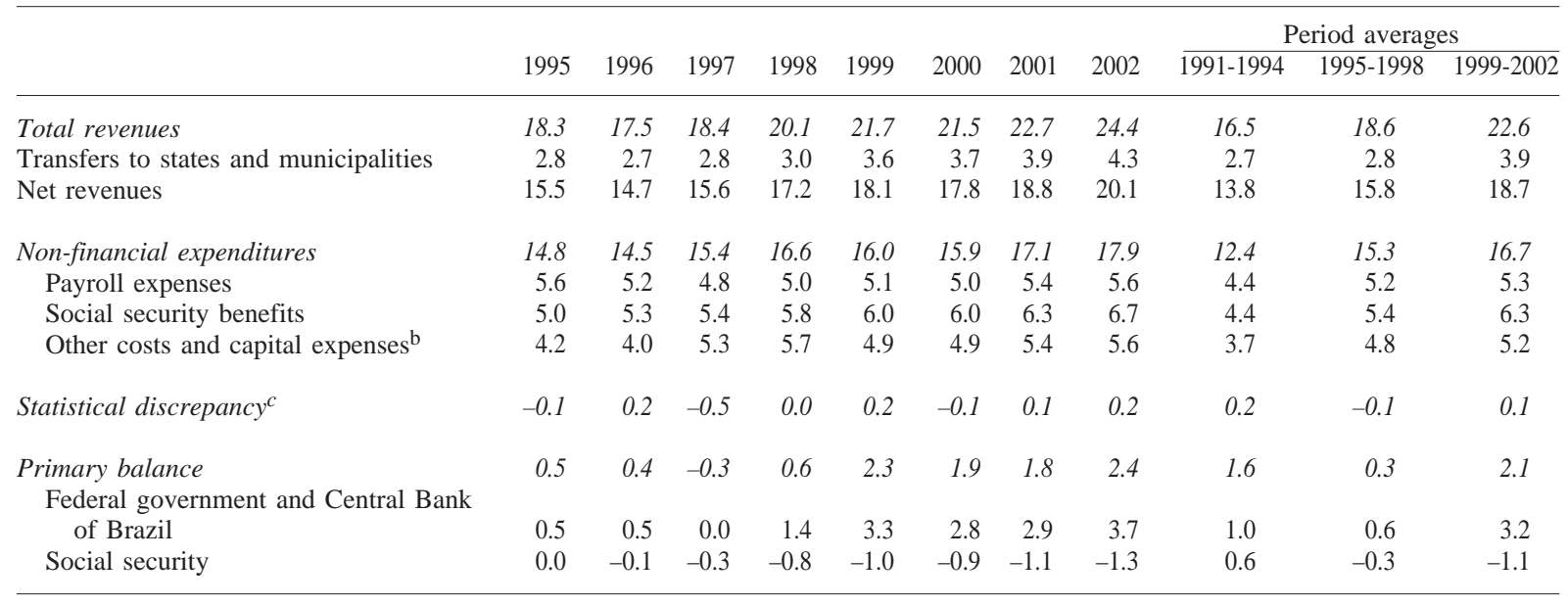

Source: Secretary of Economic Policy, Ministry of Finance.

a The minus sign indicates a deficit.

b Includes Central Bank primary balance.

c A positive figure indicates an increase in the primary balance surplus.

- Fiscal revenues increased significantly throughout the period. Gross federal government revenues increased from an average of $16.5 \%$ of GDP in $1991-1994$ to $22.6 \%$ in $1999-2002$.

- At same time, federal government non-financial expenditure grew considerably. All the major categories contributed to this expenditure growth. Between 1991-1994 and 1999-2002, payroll expenditure (mainly due to the weight of retired workers), social security benefits and "other expenses" (excluding transfers to states and municipalities, payrolls and social welfare benefits) increased by $0.9,1.8$ and 1.5 percentage points of GDP respectively. In addition, transfers to states and municipalities grew by $1.2 \%$ of GDP between the same periods. 
a) Fiscal revenues

For the federal government, the two major sources of additional revenues were: i) the provisional financial transactions contribution (CPMF), which was introduced as a permanent tax (IPMF) at the end of 1993, since when it has been abolished and reintroduced several times; ii) the contribution to the financing of the social security system (COFINs), which was associated with increases in tax rates and a series of court rulings favouring the government, thanks to which resistance to the introduction of the contribution during the early part of the decade was overcome. ${ }^{12}$ Between them, these two contributions accounted for about two thirds of the change in revenue between 1991-1994 and 1999-2002. At the same time, there was a continuous decline in industrial products tax (IPI) revenues (table 4).

Federal expenditure as a proportion of GDP was contained in 1999-2000 and began to grow again in 2001-2002. A detailed analysis of non-financial expenditures follows. ${ }^{13}$

\section{b) Payroll expenses}

Federal government payroll expenses rose from 18.5 billion reais in 1995 to 33.2 billion reais in 2001 in nominal terms, despite the fact that public employees' pay was "frozen" between the two dates; the first linear adjustment in such salaries since 1995 occurred only in 2002. The reason for this seeming paradox is that, over time, almost every category benefited from career reviews, adjustments to the "curve", promotions, etc.

Another important component of total government payroll spending was the expenditure on public-sector retirees. Overall payroll expenditure was 5.6\% of GDP in 2002 compared to $5 \%$ in 1994 , as the reduction in active duty employee payroll expenses was more than offset by the increase in expenditure on public-sector retirees, particularly military personnel. The combination of population ageing and indulgent retirement rules for

\footnotetext{
12 From the federal government's point of view, it made sense to give priority to an adjustment funded from these contributions rather than from taxes such as income tax or the industrial products tax (IPI); as these contributions are not shared with states and municipalities, the entire revenue gain remains with the federal government. Conversely, in the case of income tax and the IPI, the net revenue gain for the federal government is much smaller as about half the revenues must go to the revenue-sharing fund of the states and municipalities.

13 See Velloso (1997) for an account of the fiscal situation at the start of the Real Plan.
}

public-sector employees contributed significantly to payroll expenses. ${ }^{14}$

\section{c) Social security benefits}

The other crucial element determining public spending was social security expenses. After the Real Plan, social security benefits were adjusted by more than inflation, resulting in an increase in their average real value. The social security index rose until 1998, marked time in 1999 due to higher inflation, and then resumed its growth trend due to the policy followed in 2000-2001 of increasing the minimum wage in real terms (figure 2). ${ }^{15}$

Social security benefits also grew during the first years of the Real Plan, the main growth item being length-of-service pension benefits, which were more expensive than other pensions (table 5). The length-ofservice pension enshrined in the Brazilian Constitution grants men and women the right to retire after 35 and

FIGURE 2

Brazil: Social security benefit index ${ }^{a}$

(Base: June $1994=100)$

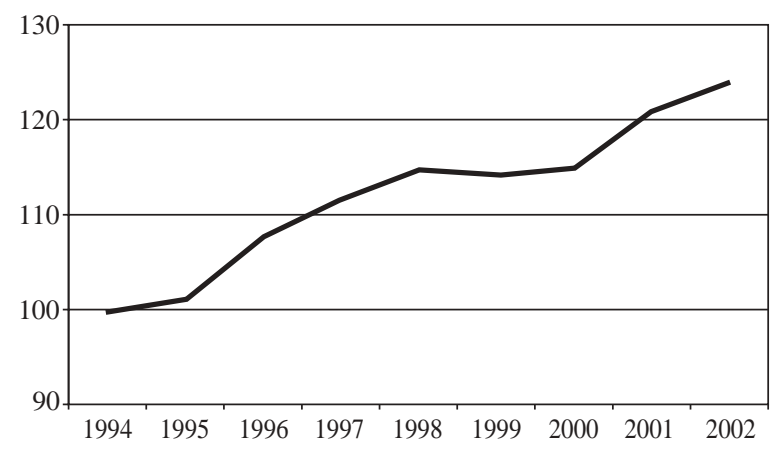

Source: Social security and authors' estimates.

a Deflated by the extended national consumer price index (IPCA).

14 Retired military personnel have generous pension benefits,
including the transfer of such benefits to unmarried daughters after
the death of the original beneficiary. Some military privileges have
been reduced over the last few years.
${ }^{15}$ The social security index was calculated by deflating the nominal
rise in social security benefits by the IPCA price index. Social security
benefits have increased in line with the minimum wage, albeit with
some divergence in a number of years. In cases where basic
remuneration was adjusted by a factor different to that used for
benefits above this floor, the index was weighted by the
multiplication factor (total number of benefits times the floor) with
reference to total with-benefits expenses. The index would allow us
to infer the potential evolution of expenditure in the event that the
quantity of benefits remained constant. 
TABLE 4

Brazil: Federal revenues

(Period averages as percentages of $G D P)^{a-b}$

\begin{tabular}{lcrr}
\hline & $1991-1994$ & $1995-1998$ & $1999-2002$ \\
\hline Total revenues $^{c}$ & 11.9 & 13.2 & 16.6 \\
Import tax $_{\text {IPI }}$ & 0.4 & 0.7 & 0.7 \\
Income tax & 2.3 & 2.0 & 1.6 \\
$\quad$ Personal & 3.7 & 4.5 & 5.6 \\
$\quad$ Corporate & 0.2 & 0.3 & 0.3 \\
Individuals $\quad 1.1$ & 1.5 & 1.7 \\
$\quad$ Capital yields & 1.3 & 1.5 & 1.7 \\
$\quad$ Other & 0.7 & 0.8 & 1.2 \\
IPMF/CPMF & 0.3 & 0.4 & 0.7 \\
IOF & 0.3 & 0.4 & 1.3 \\
COFINS & 0.7 & 0.4 & 0.3 \\
PIS/PASEP & 1.5 & 2.2 & 3.7 \\
Contribution on net profits & 1.1 & 0.9 & 1.0 \\
Civil service social security contributions & 0.7 & 0.9 & 0.8 \\
Other & 0.1 & 0.3 & 0.3 \\
Memorandum items & 1.2 & 0.9 & 1.3 \\
$\quad$ Tax burden & & & \\
$\quad$ ICMS & 25.7 & 6.7 & 7.0 \\
\hline
\end{tabular}

Source: Federal Revenue Secretary, Brazilian Geographical and Statistical Institute (IBGE).

a $\quad$ IPI $=$ Industrialized products tax.

$\mathrm{IPMF} / \mathrm{CPMF}=$ Provisional financial transactions tax/provisional financial transactions contribution .

$\mathrm{IOF}=$ Financial operations tax.

COFINS $=$ Contribution to the financing of the social security system.

PIS/PASEP $=$ Social Integration Programme/Public Servants Asset Formation Programme.

ICMS $=$ Sales tax on merchandise and services.

b Data differ from those of table 3 because of different criteria for settling accounts.

c Not including social security contributions.

TABLE 5

Brazil: Structure and growth of social security benefits

\begin{tabular}{lcrr}
\hline & $\begin{array}{c}\text { As percentage of legal minimum wage } \\
\text { (as of December 2002) }\end{array}$ & \multicolumn{2}{c}{$\begin{array}{c}\text { Average annual growth }(\%) \\
1994-1998\end{array}$} \\
\hline Total benefits & 164 & 4.2 & 3.5 \\
Social security & 172 & 3.7 & 3.4 \\
Pensions & 187 & 4.1 & 2.9 \\
$\quad$ By retirement age & 113 & 1.9 & 3.4 \\
$\quad$ By length of service & 360 & 11.5 & 2.2 \\
$\quad$ For disability & 135 & 1.0 & 2.5 \\
Allowances & 130 & 3.8 & 3.0 \\
Other & 224 & -3.0 & 7.3 \\
Aid support & 114 & 7.3 & 12.6 \\
\end{tabular}

Source: Ministry of Welfare and Social Assistance (various years).

30 years of contributions, respectively, which can reduce the retirement age considerably. From 1995 to 1998, length-of-service pension benefits increased by an annual average of $11.5 \%$, compared to $4.2 \%$ for overall benefits (table 5). This situation has changed in recent years with the approval of the social security reform and the consequent reduction in retirement applications. Lastly, the number of social security 
TABLE 6

Brazil: Real growth of federal government non-financial expenditure ${ }^{a}$

(Percentage averages)

\begin{tabular}{lccc}
\hline & $1994-1998$ & $1998-2002$ & $1994-2002$ \\
\hline Non-financial expenditure & 7.0 & 4.6 & 5.8 \\
$\quad$ Payroll expenses & 2.0 & 4.2 & 3.1 \\
$\quad$ Social security benefits & 7.4 & 5.0 & 6.2 \\
$\quad$ Transfers to states and municipalities & 6.6 & 11.0 & 8.8 \\
Other costs and capital expenditure & 12.3 & 0.7 & 6.3 \\
Memorandum item & & & 2.1 \\
Real GDP growth & 2.6 & 2.1 & \\
\hline
\end{tabular}

Source: Economic Policy Secretariat, Ministry of Finance.

a Implicit GDP deflator.

b Includes Central Bank primary balance.

beneficiaries increased at rates above GDP growth, leading to an increase in the ratio of social security expenditure to GDP. This was partly associated with the increase in the assistance component of social welfare, which covers people on the minimum wage who have never previously contributed to social security.

\section{d) Other costs and capital (ocC) expenses}

The major increase in occ expenses took place in 1997-1998 (table 3). By contrast, they were squeezed in 1999-2000, following the signing of the Stand-By Agreement with IMF at end-1998. ${ }^{16}$ However, they increased in 2001-2002, partly reflecting their increasing rigidity as some public-sector agencies committed to higher expenditure to protect their resources. The division of responsibility between the executive and legislature for the increasing rigidity of OCC expenses is a matter of controversy. ${ }^{17}$

The share of non-discretionary expenditures in the OCC expenses increased substantially, from $20 \%$ in 1999 to $60 \%$ in 2002 , including health, employment insurance, and the anti-poverty fund. Most of the commitments are relatively new ones, arising from legal or constitutional provisions approved in recent years. The existence of this spending rigidity reduces

\footnotetext{
${ }^{16}$ In 1999, other costs and capital expenses excluding the Workers' Protection Fund (FAT) fell by $11 \%$ in nominal terms. At the start of 1999, this item was considered impossible to cut despite the increase seen since 1994. The contraction of 1999 suggests that OCC expenses in previous years could have been lower.

17 Although the executive bears most of the responsibility for the increasing rigidity of occ expenses, in some years the rigidity was the result of larger commitments due to legislature initiatives such as the anti-poverty fund.
}

FIGURE 3

Brazil: Federal government non-financial expenditure $^{\mathrm{a}}$

(Billions of 2002 reais)

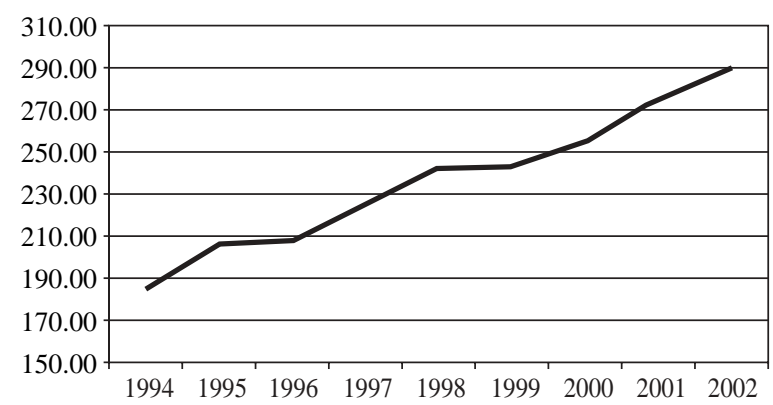

Source: National Treasury, Ministry of Finance.

a Expenditure corrected by the implicit GDP deflator.

the authorities' room for fiscal adjustment in the short run.

Summing up, overall non-financial expenditure, including transfers to states and municipalities and the Central Bank deficit, grew by $7.0 \%$ a year in real terms during the first Cardoso administration and $4.6 \%$ a year during the second. Expenditure growth was well above real GDP growth during the same period (table 6 and figure 3 show expenditures deflated by the implicit GDP deflator).

\section{States and municipalities}

The primary balances of states and municipalities deteriorated progressively from 1994 to 1998 and improved gradually after 1998, particularly in the case 
of the states (tables 1 and 2). The improvement in state and municipal primary balances, which was substantial, was due partly to the constraints placed on their budgets by the bilateral agreements they signed with the federal government to refinance their debts, partly to the provisions of the Fiscal Responsibility Act. Their finances also benefited from higher tax revenues on some products and services that experienced large price increases and represented a large share of their revenues, such as oil, telecommunications and electricity.

The efforts to control state and municipal finances started in 1993, when Cardoso was still Finance Minister at the end of the Collor administration. On 17 March 1993, an amendment to paragraph 4 of article 167 of the Constitution was passed, allowing the states to pledge their own revenues and federal government transfers as collateral for debt rescheduling agreements with the federal government. This amendment was instrumental in the success of the bilateral debt agreements and meant that all later disputes brought by states to the Supreme Court were defeated. On 5 November 1993 Law 8727 was passed, allowing the federal government to refinance state debts with five federal banks, provided that the states paid over at least $11 \%$ of their revenues and allowed transfers from the federal government to be withheld if payments were missed. The first bilateral debt agreements under the terms of this law were signed in 1994. On 30 November 1995, the National Monetary Council approved Vote 162/95, making debt refinancing conditional for the first time on fiscal commitments by the states. These three measures paved the way for the passing of Law 9496 of 1997, which allowed the refinancing of states' remaining bonded debt. ${ }^{18}$ Under the 1997 law, the bilateral agreements between the federal government and states and municipalities established minimum monthly payments of $13 \%$ to $15 \%$ of revenues (with a ceiling of $30 \%$ ) over 30 years, and real interest rates of $6 \%$ a year. The refinancing of the debts was collateralized with federal government transfers and revenues from the sales tax on merchandise and services (ICMS, the state VAT), which effectively prevented states from defaulting on their obligations to the federal government since such a default would block transfers and allow the National

\footnotetext{
${ }^{18}$ In the case of the states, the first bilateral agreement under Law 9496 was signed in May 1997 and the last in October 1999. In the case of the municipalities, the first agreement was signed in July 1999 and the last in May 2000.
}

Treasury to appropriate states' ICMS revenues directly. These bilateral agreements prompted states and municipalities to modify their fiscal stances and generate primary surpluses to meet their debt obligations.

In addition to the bilateral agreements, the other important institutional landmark was the passing of the Fiscal Responsibility Act in 2000. Among other things, this set ceilings for public-sector payrolls in terms of government revenues and prohibited the refinancing of state and municipal debts by the federal government, putting an end to the moral hazard resulting from the private sector lending to state and municipal governments in the expectation that the National Treasury would ultimately pick up the bill. For the first time states and municipalities faced a tight budget constraint.

The fiscal adjustment at state and municipal level also benefited from the increase in state tax revenues, as well as transfers from the federal government. After 1998, ICMS (state VAT) revenues increased, reflecting improved fiscal administration by the governors elected that year and the fact that ICMS revenue was partly concentrated in sectors that led the recovery in growth, such as telecommunications, and/or underwent tariff increases, such as petrol and oil derivatives in general. Between 1998 and 2002, ICMS revenue rose from 6.7\% to $7.9 \%$ of GDP. At the same time, transfers to states and municipalities rose from $3 \%$ to $4.3 \%$ of GDP, as a result of changes made to legislation after pressure from state governors, particularly the revision of the Kandir Law. ${ }^{19}$ Owing to these two effects, state and municipal revenues rose by $2.5 \%$ of GDP during the period 1999-2002, explaining most of the improvement in their primary balance.

\section{Public-sector enterprises}

The primary balance of public-sector enterprises has also improved since 1999 (table 7). In the case of federal enterprises, the improvement was mainly due to the results of the State oil company (Petrobras), which benefited from the increase in international oil

\footnotetext{
19 The Kandir Law was negotiated between the federal and state governments before the 1999 devaluation to provide a tax incentive for exporters: states would lift ICMS tax on exports in exchange for compensation payments from the federal government. Subsequently, the states claimed that the compensation payments had been wrongly calculated, and succeeded in obtaining from the federal government a commitment to provide substantial supplementary transfers over a period of several years.
} 
Brazil: Primary balance of public-sector enterprises

(Percentages of GDP $)^{a}$

\begin{tabular}{|c|c|c|c|c|c|c|c|c|c|}
\hline & 1994 & 1995 & 1996 & 1997 & 1998 & 1999 & 2000 & 2001 & 2002 \\
\hline Total balance & 1.2 & -0.1 & 0.1 & 0.1 & -0.4 & 0.7 & 1.1 & 0.9 & 0.7 \\
\hline Federal enterprises & 1.6 & 0.4 & 0.3 & 0.3 & -0.2 & 0.7 & 0.9 & 0.6 & 0.5 \\
\hline Revenues & 9.0 & 8.8 & 8.7 & 8.2 & 7.0 & 6.8 & 8.1 & 8.4 & $\ldots$ \\
\hline Non-financial expenditure & 9.0 & 8.5 & 8.3 & 7.9 & 7.2 & 6.7 & 7.5 & 8.5 & $\ldots$ \\
\hline Wages & 1.6 & 1.4 & 1.4 & 1.1 & 0.9 & 0.6 & 0.6 & 0.5 & $\ldots$ \\
\hline Other costs & 5.8 & 5.6 & 5.0 & 4.9 & 4.5 & 4.8 & 5.6 & 6.4 & $\ldots$ \\
\hline Investments & 1.5 & 1.3 & 1.6 & 1.6 & 1.3 & 0.8 & 0.8 & 1.0 & 1.3 \\
\hline Other capital expenses & 0.1 & 0.2 & 0.4 & 0.4 & 0.5 & 0.6 & 0.5 & 0.5 & $\ldots$ \\
\hline Adjustments & 1.7 & 0.2 & -0.2 & 0.0 & -0.1 & 0.6 & 0.3 & 0.7 & $\ldots$ \\
\hline State and municipal enterprises & 0.0 & -0.5 & -0.2 & -0.2 & -0.1 & 0.0 & 0.1 & 0.3 & 0.3 \\
\hline State enterprises & $\ldots$ & -0.5 & -0.2 & -0.2 & -0.1 & 0.0 & 0.1 & 0.3 & 0.3 \\
\hline Municipal enterprises & $\ldots$ & 0.0 & 0.0 & 0.0 & 0.0 & 0.0 & 0.0 & 0.0 & 0.0 \\
\hline
\end{tabular}

Source: Ministry of Planning and Central Bank of Brazil.

a The minus sign indicates a deficit.

prices in 1999. This rise in international market prices increased domestic prices but affected only part of Petrobras's costs, since most of the oil products it sells derive from domestic production. The improvement in Petrobras's balance also created some scope for publicsector enterprises in general to invest more without affecting the PSBR. ${ }^{20}$
The primary balance of state and municipal enterprises improved because of the privatization of loss-making enterprises and changes in the management of those that remained in state hands. In general, state authorities appointed managers who were committed to efficiency, and they faced a much more competitive environment.

\section{IV}

\section{Temporary revenue sources}

Making up for the gradual loss of temporary revenues will be a challenge. The adjustment will have to include a combination of spending cuts, the phasing out of temporary revenues, and possibly the transformation of some temporary revenues into permanent ones.

At the end of 1993, the provisional financial transactions tax (IPMF) was approved, only to be abolished a year later. At that point the government introduced "temporary" or "one-off" revenue-raising measures, and this would become a common practice

\footnotetext{
${ }^{20}$ In 2001-2002 the average aggregate primary surplus for federal enterprises, including Itaipu Binacional, was approximately $0.5 \%$ of GDP. This primary surplus breaks down into a surplus of $0.4 \%$ of GDP for Petrobras and $0.2 \%$ of GDP for Itaipu, and a primary deficit of $0.1 \%$ for the Eletrobrás group, explained by the fall in revenues due to the energy crisis, combined with an increase in investments. The other federal enterprises generated a primary result close to zero.
}

in subsequent years. ${ }^{21}$ Taken all together, extraordinary revenues peaked at over 3\% of GDP in 1999, and continued to contribute an average of $2.5 \%$ of GDP in 2000-2002 (table 8).

While the IPMF was abolished in 1994, the same tax was reintroduced as the provisional financial transactions contribution (CPMF) in 1997 and extended in subsequent years. In 1994, the Social Emergency Fund (FSE) was created as a mechanism whereby the federal government retained part of its transfers to states and municipalities for a two-year period (1994 and 1995). This fund was

\footnotetext{
21 "Temporary revenues" means a source of adjustment that is not protracted over time. The definition of what exactly constitutes such revenues is to some extent arbitrary. We include in that category only strictly temporary revenues (in force for only a year) or revenues that would tend to disappear in the absence of any modification to the legislation giving rise to them.
} 
TABLE 8

Brazil: Temporary federal government revenues

(Percentages of GDP)

\begin{tabular}{|c|c|c|c|c|c|c|c|c|}
\hline & 1995 & 1996 & 1997 & 1998 & 1999 & 2000 & 2001 & 2002 \\
\hline Total & 0.5 & 0.5 & 1.4 & 2.8 & 3.2 & 2.3 & 2.3 & 2.9 \\
\hline IPMF/CPMF ${ }^{\mathrm{a}}$ & 0.0 & 0.0 & 0.8 & 0.9 & 0.8 & 1.3 & 1.5 & 1.5 \\
\hline Concessions & 0.0 & 0.0 & 0.2 & 1.0 & 0.9 & 0.5 & 0.4 & 0.3 \\
\hline Additional personal income tax & 0.0 & 0.0 & 0.0 & 0.1 & 0.1 & 0.1 & 0.1 & 0.1 \\
\hline Additional income tax on securities & 0.0 & 0.0 & 0.0 & 0.3 & 0.0 & 0.0 & 0.0 & 0.0 \\
\hline End of COFINS rebate & 0.0 & 0.0 & 0.0 & 0.0 & 0.3 & 0.3 & 0.3 & 0.3 \\
\hline Fiscal stability fund (FEF) & 0.5 & 0.5 & 0.4 & 0.3 & 0.3 & 0.0 & 0.0 & 0.0 \\
\hline Collection of arrears & 0.0 & 0.0 & 0.0 & 0.2 & 0.6 & 0.1 & 0.0 & 0.7 \\
\hline
\end{tabular}

Source: Authors' estimates.

a $\quad$ IPMF/CPMF $=$ Provisional financial transactions tax/provisional financial transactions contribution .

subsequently renewed in 1996 for a year and a half, with the same characteristics and a new name (Fiscal Stabilization Fund, FEF). The FEF was further renewed - albeit subject to a gradual increase in transfers to municipalities - for another two and a half years in mid1997, not being abolished until December 1999.

In addition, significant revenues were generated from the auction of mobile telephony concessions and the privatization of the State telecommunications company (Telebras). Part of the Telebras privatization receipts $(40 \%)$ were treated as tax revenues for the purpose of determining the public-sector deficit, by contrast with other privatizations, which did not affect the public-sector deficit. Also, overdue taxes were collected after relief had been granted on penalty interest for arrears. ${ }^{22}$

\section{$\mathrm{V}$}

\section{Hidden liabilities and the growth of public debt}

The ratio of public debt to GDP, including the monetary base, fell from a peak of $56 \%$ in 1984 to $30 \%$ in 1994 due to a combination of high seigniorage, low operating deficits in the first half of the 1990s, belowinflation correction of the face value of the debt, and accumulated economic growth of $32 \%$ over the period 1985-1994. Between 1994 and 1998 the ratio rose sharply, mainly as a result of persistent public-sector

\footnotetext{
22 Other measures were also implemented, including a personal income tax surcharge for higher bracket taxpayers from 1998 onward; exceptionally, in 1998, the double taxation of income from financial applications; an income tax surcharge on profits made by certain operations from the 1999 currency devaluation; the temporary suspension, from 1999 onward, of the tax-deductibility of a portion of the contribution to the financing of the social security system (COFINS) that was initially allowed for the purpose of paying corporate income tax; the payment of overdue tax by pension funds in 2002 , etc.
}

deficits. By the end of 1998 the government had run out of alternatives for financing the deficit (table 9): seigniorage was low, a return to inflation was unanimously rejected by all political groups, the high level of external debt had led to a collapse in the exchange rate, the domestic debt was becoming ever costlier to roll over and privatization was coming to an end. Under these circumstances, the government initiated the process of fiscal adjustment under an IMFsupported programme. ${ }^{23}$

During the period 1995-1998 the total public debt increased, owing mainly to the issuance of public securities and partly to the transfer of individual state debts to the federal government. This increase in the

\footnotetext{
23 See Pastore (1995), Tanner (1995) and Rocha (1997) for an account of the historical roots of Brazil's public-sector debt.
} 
TABLE 9

Brazil: Net public-sector debt

(Percentages of GDP)

\begin{tabular}{|c|c|c|c|c|c|c|c|c|c|}
\hline & 1994 & 1995 & 1996 & 1997 & 1998 & 1999 & 2000 & 2001 & 2002 \\
\hline Total debt ${ }^{\mathrm{a}}$ & 30.0 & 30.6 & 33.3 & 34.3 & 41.7 & 48.7 & 48.8 & 52.6 & 55.5 \\
\hline Federal government & 13.0 & 13.3 & 16.0 & 18.6 & 24.9 & 29.8 & 30.6 & 32.7 & 35.3 \\
\hline States and municipalities & 9.9 & 10.7 & 11.5 & 12.9 & 14.2 & 16.2 & 16.0 & 18.3 & 18.5 \\
\hline Public-sector enterprises & 7.1 & 6.6 & 5.8 & 2.8 & 2.6 & 2.7 & 2.2 & 1.6 & 1.7 \\
\hline Domestic debt & 21.5 & 25.1 & 29.4 & 30.0 & 35.5 & 38.4 & 39.2 & 42.2 & 41.2 \\
\hline Federal government & 6.7 & 9.8 & 14.4 & 16.7 & 20.8 & 21.9 & 23.2 & 24.5 & 22.9 \\
\hline Monetary base & 3.6 & 3.1 & 2.4 & 3.6 & 4.2 & 4.6 & 4.2 & 4.2 & 4.6 \\
\hline Securitized debt ${ }^{b}$ & 11.7 & 15.6 & 21.4 & 28.1 & 34.5 & 38.6 & 41.8 & 48.1 & 37.8 \\
\hline Central Bank credits & -4.6 & -5.3 & -8.5 & -7.8 & -5.6 & -4.4 & -3.7 & -3.2 & -2.6 \\
\hline Refinancing of states and municipalities & & & & & & & & & \\
\hline and PROES & 0.0 & 0.0 & 0.0 & -5.4 & -9.3 & -12.4 & -13.4 & -13.9 & -13.7 \\
\hline Workers' Protection Fund (FAT) & -2.0 & -2.5 & -2.5 & -2.6 & -3.5 & -3.9 & -4.4 & -4.9 & -4.8 \\
\hline Other & -2.0 & -1.1 & 1.6 & 0.8 & 0.5 & -0.6 & -1.3 & -5.8 & 1.6 \\
\hline States and municipalities & 9.6 & 10.4 & 11.1 & 12.4 & 13.5 & 15.3 & 15.1 & 17.3 & 17.1 \\
\hline Refinancing of states and municipalities & 0.0 & 0.0 & 0.0 & 5.4 & 9.3 & 12.4 & 13.4 & 13.9 & 13.7 \\
\hline Securitized debt & 4.8 & 5.6 & 6.2 & 4.3 & 2.4 & 1.3 & 0.2 & 0.2 & 0.1 \\
\hline Other & 4.8 & 4.8 & 4.9 & 2.7 & 1.8 & 1.6 & 1.5 & 3.2 & 3.3 \\
\hline Public-sector enterprises & 5.2 & 4.9 & 3.9 & 0.9 & 1.2 & 1.2 & 0.9 & 0.4 & 1.2 \\
\hline External debt & 8.5 & 5.5 & 3.9 & 4.3 & 6.2 & 10.3 & 9.6 & 10.4 & 14.3 \\
\hline Federal government & 6.3 & 3.5 & 1.6 & 1.9 & 4.1 & 7.9 & 7.4 & 8.2 & 12.4 \\
\hline States and municipalities & 0.3 & 0.3 & 0.4 & 0.5 & 0.7 & 0.9 & 0.9 & 1.0 & 1.4 \\
\hline Public-sector enterprises & 1.9 & 1.7 & 1.9 & 1.9 & 1.4 & 1.5 & 1.3 & 1.2 & 0.5 \\
\hline \multicolumn{10}{|l|}{ Memorandum items } \\
\hline Fiscal debt ${ }^{\mathrm{d}}$ & 30.0 & 30.6 & 31.4 & 34.2 & 40.6 & 40.7 & 40.9 & 40.8 & 36.1 \\
\hline Balance sheet adjustment (stock) & 0.0 & 0.0 & 1.9 & 0.1 & 1.1 & 8.0 & 7.9 & 11.8 & 19.4 \\
\hline Privatization & 0.0 & 0.0 & -0.1 & -2.0 & -3.3 & -3.8 & -5.2 & -4.8 & -4.0 \\
\hline Other & 0.0 & 0.0 & 2.0 & 2.1 & 4.4 & 11.8 & 13.1 & 16.6 & 23.4 \\
\hline Domestic debt adjustment & 0.0 & 0.0 & 0.0 & 0.0 & 0.4 & 4.2 & 4.6 & 6.0 & 9.6 \\
\hline External debt adjustment & 0.0 & 0.0 & 0.1 & 0.2 & 0.5 & 3.2 & 3.8 & 4.4 & 8.0 \\
\hline Other & 0.0 & 0.0 & 1.9 & 1.9 & 3.5 & 4.4 & 4.7 & 6.2 & 5.8 \\
\hline Dollar debt & 9.5 & 6.3 & 5.9 & 8.7 & 13.5 & 19.6 & 19.6 & 25.0 & 28.9 \\
\hline (as percentage of total debt) & 31.7 & 20.6 & 17.7 & 25.4 & 32.4 & 40.2 & 40.2 & 47.5 & 52.1 \\
\hline
\end{tabular}

Source: Central Bank of Brazil.

a Includes the monetary base and balance sheet adjustments.

b Includes swap operations from 2002.

c Central Bank lending to financial institutions.

d Debt originating from issuance of public securities only.

federal government's liabilities did not immediately affect the net public debt, but it was not neutral as the assets and liabilities in question involved different costs and maturities (Werneck and Bevilacqua, 1998). As a consequence, the total public-sector debt, including the monetary base, rose by $12 \%$ of GDP between 1994 and 1998, while the domestic debt in public securities increased by $23 \%$ of GDP in the same period.

After 1999, despite the adjustment of the primary balance, total public debt increased because of the impact of the devaluation on the foreign public debt and the dollar-denominated domestic public debt, whose share of the total had risen sharply over the previous two years. At the time of devaluation, the dollar-denominated public debt represented $14 \%$ of GDP (or 30\% of the total public debt). With the sharp fall of the Brazilian currency against the dollar in 20002002, the dollar-denominated debt increased substantially in value, reaching $29 \%$ of GDP (or $50 \%$ of total public debt) in late 2002 (table 9).

Central to the evolution of the public-sector debt that began in the mid-1990s were the "balance sheet adjustments" (Passini, 2000; Kawall, Costa and Gomes, 2000) resulting from three factors: 
- the recognition of old debts that had affected aggregate demand in the past but were not properly registered in the fiscal statistics at the time (the so-called "skeletons");

- variations in the value of the debt due to exchange-rate fluctuations, and

_ $\quad$ privatization receipts, which were used to reduce the public debt.

Prior to 1995, these factors were not clearly recorded in the fiscal statistics. In all, between 1999 and 2002 the sum of the first two effects represented a cumulative increase of $19 \%$ of GDP in the publicsector debt, while privatization reduced the debt by $1 \%$ of GDP, the result being a net increase of about $18 \%$ of GDP. This partly explains why, although Brazil met its fiscal commitments and even exceeded the targets set in its agreement with the IMF, the public-sector debtto-GDP ratio increased from its pre-devaluation level of 1999. ${ }^{24}$

\section{VI}

\section{The fiscal attitude of the authorities}

The authorities did not display the same rigour in controlling the public-sector accounts prior to 1998 as they did after 1999 in the context of an external and fiscal crisis. ${ }^{25}$ Expenditures that were under direct government control and not subject to legal or constitutional restrictions expanded vigorously during the first Cardoso administration, and proposals for adopting fiscal targets did not receive any support before 1998 .

As had previously happened for more than two decades, Brazil experienced a situation of "soft budget constraint" (Kornai, 1986, p. 4). The natural tendency of a "soft budget constraint" is for the adjustment to take place either through higher inflation, when monetary policy is accommodating, or through higher public-

\footnotetext{
24 The exchange rate has a twofold impact on the debt through a balance sheet adjustment: the foreign public debt increases, as does the dollar-denominated domestic debt. This effect was particularly strong in 1999, 2001 and 2002, and explains the jumps in the ratio of debt to GDP despite the solid primary results observed after 1998 . ${ }^{25}$ A more generous view of the official stance prior to 1999 would acknowledge that during 1995-1998 the government had an ambitious reform agenda involving the passing of constitutional amendments, some of which were important for the subsequent fiscal adjustment (such as social welfare reform, which took a long time to negotiate with Congress). The focus on the reforms, it can be argued, led to a relaxation in short-term fiscal flows, favoured by a benign external environment that financed growing current-account deficits until 1999. To conclude that, in such an environment, it would have been possible to achieve the same type of budgetary constraint during 1995-1998 as was observed during 1999-2002 is counterfactual and not easy to demonstrate.
}

sector debt, when a tight monetary policy means that fiscal imbalances leave prices unaffected in the short term, only to aggravate future fiscal imbalances by way of a higher interest burden (Sargent and Wallace, 1981).

The crisis of 1998-1999 changed this situation, strengthening the advocates of tighter fiscal policy in the Cardoso administration. In fact, the fiscal adjustment was imposed by circumstances, since without it Brazil would certainly have headed towards a domestic public debt moratorium. Sure enough, President Cardoso - who was convinced that higher taxes and spending cuts were an important precondition for IMF support- gave the necessary backing to the austere fiscal measures required and took the lead in the negotiations with the National Congress to pass the necessary enabling legislation. Under these conditions, the relatively passive fiscal attitude of the first Cardoso administration gave way to active support for a fiscal effort to curb the rising public debt.

Two qualifications are important. First, rather than a change of attitude on the part of the authorities, some have suggested that there was simply a greater concern with financing expenditure adequately, since the public-sector spending-to-GDP ratio was never reduced. Second, the adjustment was partly based on temporary revenues such as the CPMF and the additional earnings of Petrobras due to the rise in fuel prices. This by no means detracts from the fiscal effort made in 19992002, but it does highlight the need to persist with and improve the adjustment over the coming years. 


\section{VII \\ The future of fiscal sustainability}

The government's attitude to fiscal policy changed dramatically with the external and fiscal crisis of 19981999. As a result, the supporters of more austere fiscal policies in Cardoso's administration had their case strengthened and were able to sway policy decisionmaking towards tighter policies of a kind which had gathered little support prior to 1998. Just 10 days before the 1998 elections, President Cardoso made a speech that gave a clear indication of the approaching austerity. He emphasized that "we have to ensure that the State lives within its means" by generating primary surpluses "that are sufficient to prevent the publicsector debt from growing at a rate above that of GDP, so that the ratio of the two is kept stable over time". ${ }^{26}$ While this might sound trivial, the contrast between the President's statement and the trend in the public debt in previous years was remarkable. Even such an obvious point would have been extremely hard to make as little as six months before. The political conditions for adopting a more austere fiscal attitude were created by the dramatic external crisis, when outflows of foreign currency reserves had reached US\$ 1 billion a day as a result not only of the overvalued exchange rate but also of the unsustainable fiscal situation.

The problem President Cardoso inherited in the mid-1990s was deep-rooted: since 1954, populist expansionary policies had alternated with brief intervals of conservative reformism. ${ }^{27}$ The crisis of 1998-1999 created the conditions for a political climate favourable to measures for addressing deep structural fiscal imbalances and, most importantly, to austerity as a norm of public administration, a genuine departure from the old fiscal extravagance. Whether this change in the authorities' fiscal attitude will last is something that the coming years will show. ${ }^{28}$

Yet the adjustment observed after 1999 was based to a large extent on increased revenues, since overall public-sector spending was unaffected in real terms. Non-financial expenditure by the federal government, including transfers to states and municipalities and the

\footnotetext{
26 Translated from Jornal do Brasil, September 24, 1998.

27 See Rabello de Castro and Ronci (1991).

28 An important element in greater fiscal control has been the improvement of public-sector statistics since 1995 .
}

small Central Bank deficit, increased continuously in real terms in every year of the eight-year period covered by the two Cardoso administrations, without exception.

Also, it seems justifiable for Brazil —whose credibility has been undermined by years of repressed hyperinflation, large deficits and rising public-sector debt - to continue to sustain large primary surpluses for several years, before gradually reducing the primary surplus at a time when this does not affect the evolution of the public-sector debt.

These aspects of Cardoso's fiscal adjustment underline the need to preserve hard-won fiscal discipline over the coming years. To improve the quality of the adjustment, it will be necessary to offset the gradual phasing out of temporary revenues by making some of these revenues permanent and by cutting public expenditure across the board in the budget. Non-discretionary expenses will also have to be reduced to make more room for fiscal adjustments in the short run.

Key to achieving fiscal sustainability has been the austere attitude of the authorities, which should be permanently embedded in the fiscal institutions. One possible alternative would be to have the Fiscal Responsibility Act complemented by a fiscal solvency act that established clear and permanent rules for public debt sustainability over the medium term, in the form of either a ceiling on borrowing requirements or a floor for the primary surplus. ${ }^{29}$ The fiscal solvency act would help to address the fiscal consequences of political fragmentation, as well as the legitimate pressure for more social spending in the coming years. Also, it could improve the trade-off between fiscal adjustment and economic growth in the short term by strengthening credibility and allowing lower interest rates. However, the outcome of any legal reform of

\footnotetext{
${ }^{29}$ While the Fiscal Responsibility Act and the refinancing of state and municipal debts placed a tight budgetary constraint on the fiscal regimes of states and municipalities, the federal government budget has not been constrained in the same way. The federal government's primary surplus targets are valid only for the current budget year and can be revised in the following year: in principle, there is no clear and durable constraint on the federal government budget that can prevent a substantial reduction in the primary surplus, leading potentially to a rising debt-to-GDP ratio.
} 
Brazil's fiscal institutions will depend crucially on policymakers and politicians understanding that fiscal sustainability is a valuable public good, and a necessary condition for economic growth. Without this understanding, any legal reform of Brazil's fiscal institutions will inevitably be short-lived.

APPENDIX

Public debt sustainability, 1995-2002

Despite Cardoso's fiscal reforms and the remarkable shift to austerity after 1999, the evidence suggests that the public debt was not sustainable either in 1995-2002 or in 1999-2002; in other words, fiscal policy was not tight enough to contain the growth in the public debt.

We follow the technique presented by Wilcox (1989) and Luporini (2000) to test for fiscal sustainability during the period from January 1995 to December 2002. This consists in testing the discounted public debt for stationarity (unit roots). If the discounted public debt were stationary (rejection of unit root hypothesis), the public debt would be sustainable on the basis of the fiscal policy followed during the sample period.

The data set consists of monthly data on the consolidated net public debt at par value. Nominal debt was divided by the general price index. The real discount factors were calculated by dividing the Special System of Clearance and Custody (SELIC) interest rate by the general price index. ${ }^{30}$ Figure A.1 shows the public debt and the discounted public debt, both expressed in December 2002 reais.

FIGURE A1

Brazil: Total net public debt

(Billions of December 2002 reais)

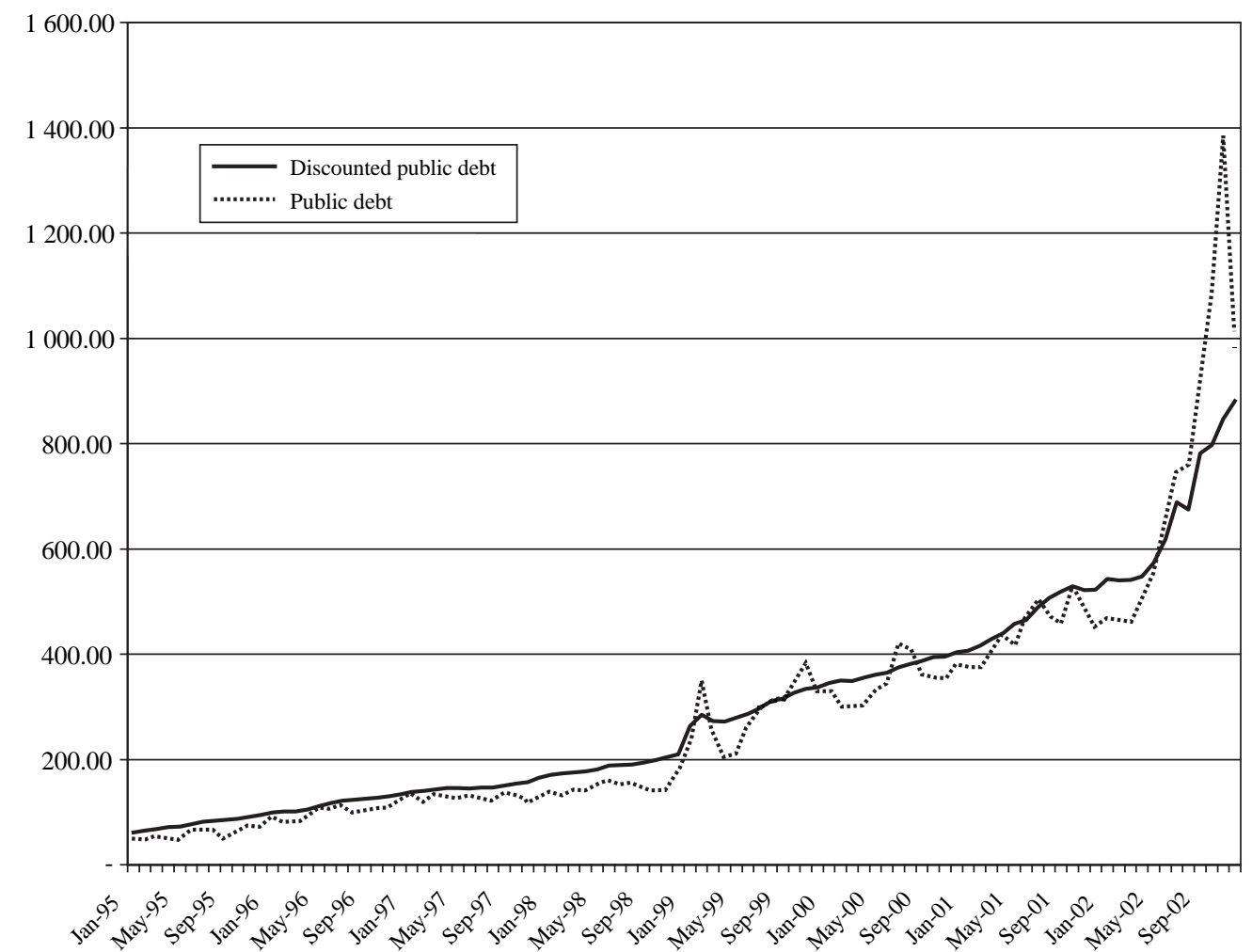

Source: Central Bank of Brazil.

${ }^{30}$ Ideally, the net-of-taxes real interest rate should be used. Estimating the net-of-tax yield on securities is virtually impossible, however, as tax rates vary between holders and there is limited information on the identity of these. 
Table A.1 summarizes the testing for stationarity of the discounted net public debt $t$ using the augmented Dickey-Fuller test. ${ }^{31}$ The unit root hypothesis is not rejected for all sample periods, confirming that, despite all government efforts, fiscal policy was not tight enough to make the public debt sustainable between January 1995 and December 2002 and between January 1999 and December 2002.

TABLE A.1

\section{Brazil: Testing for stationarity of the discounted public debt}

\begin{tabular}{|c|c|c|c|}
\hline Sample period & January 1995-December 2002 & January 1995-December 1998 & January 1999-December 2002 \\
\hline Null hypothesis of unit root & $\begin{array}{l}\text { Not rejected at } \\
10 \% \text { level }\end{array}$ & $\begin{array}{l}\text { Not rejected at } \\
10 \% \text { level }\end{array}$ & $\begin{array}{l}\text { Not rejected at } \\
10 \% \text { level }\end{array}$ \\
\hline $\begin{array}{l}\text { Augmented Dickey-Fuller test } \\
\text { (Probability) }\end{array}$ & $\begin{array}{r}0.17651 \\
(-0.9976)\end{array}$ & $\begin{array}{r}-3.048911 \\
(0.1281)\end{array}$ & $\begin{array}{r}-1.880546 \\
(0.6522)\end{array}$ \\
\hline \multicolumn{4}{|l|}{ Test critical values } \\
\hline $1 \%$ level & -4.045236 & -4.118444 & -4.118444 \\
\hline $5 \%$ level & -3.451959 & -3.486509 & -3.486509 \\
\hline $10 \%$ level & -3.151440 & -3.171541 & -3.171541 \\
\hline Number of lags & 6 & 2 & 6 \\
\hline Number of observations & 96 & 48 & 48 \\
\hline
\end{tabular}

Source: Authors' estimates.

\section{Bibliography}

Alem, A.C. and F. Giambiagi (1999): Finanças publicas: teoria e pratica no Brasil, Rio de Janeiro, Editora Campus.

Barbosa, F., A. Salazar Brandão and C. de Faro (1989): Fiscal Reform and Stabilization: the Brazilian Experience, Rio de Janeiro, Fundação Getulio Vargas, August.

Central Bank of Brazil (2000): Relatório Focus, Brasilia, 16 October.

Enders, W. (1995): Applied Econometric Time Series, New York, John Wiley and Sons.

Ferreira, A. and G. Tullio (2002): The Brazilian exchange rate crisis of January 1999, Journal of Latin American Studies, vol. 34, No. 1, New York, Cambridge University Press.

Garcia, M.G.P. and T. Didier (2000): Taxa de juros, risco cambial e risco Brasil, document presented at the III Encontro da Economia da Região Sul, September, Anpec Sul.

Giambiagi, F. (1997): Necessidades de financiamento do setor publico 1991/96: bases para a discussão do ajuste fiscal no Brasil, Pesquisa e Planejamento Econômico, vol. 27, No. 1, Rio de Janeiro, Institute of Applied Economic Research (IPEA), April.

Giambiagi, F. and M. Ronci (2004): Fiscal Policy and Debt Sustainability: Cardoso's Brazil, 1995-2002, IMF Working Paper WP/04/156, Washington, D.C., August.

Jornal do Brasil (1998): 24 September.

Kawall, C.L.F, R. Costa, and T.G. Gomes (2000): A dívida publica e os esqueletos, Economic Update, Citibank, 29 September.

Kornai, J. (1986): The soft budget constraint, Kyklos, vol. 39, No. 1, Cambridge, Blackwell Publishing.

31 We carried out the augmented Dickey-Fuller testing following the methodology described by Enders (1995).
Luporini, V. (2000): Sustainability of the Brazilian fiscal policy and Central Bank independence, Revista Brasileira de Economia, vol. 54, No. 2, Rio de Janeiro, Fundação Getulio Vargas, January/March.

Mendonça de Barros, J.R. and M.F. Almeida (1996): A reestruturação do sistema financeiro, Gazeta Mercantil, 26 August.

Ministry of Welfare and Social Assistance (various years): Anuario estadístico da previdência social.

North, D.C. (1990): Institutions, Institutional Change and Economic Performance, Cambridge, Cambridge University Press.

Ornelas, W. and S. Vieira (1999): As novas regras da previdência social, Conjuntura Econômica, vol. 53, No. 11, Rio de Janeiro, Fundação Getulio Vargas, November.

Passini, S. (2000): Fiscal Skeletons in Brazil, Stanford, UBS Warburg, September.

Pastore, A. (1995): Déficit público, a sustentabilidade das dividas interna e externa, segnoriagem e inflação: uma análise do regime monetário brasileiro, Revista de Econometria, vol. 14, No. 2, Rio de Janeiro, Sociedad Brasileira de Econometria.

Rabello de Castro, P. and M. Ronci (1991): Sixty years of populism in Brazil, in R. Dornbusch and S. Edwards (eds.), The Macroeconomics of Populism in Latin America, Chicago, The University of Chicago Press.

Rezende, A.L. (1990): Estabilização e reforma: 1964-1967, in M. de Paiva Abreu (ed.), A ordem do progresso: cem anos de política econômica republicana, 1889-1989, Rio de Janeiro, Editora Campus.

Rocha, F. (1997): Long-run limits on the Brazilian government debt, Revista Brasileira de Economia, vol. 51, No. 4, Rio de Janeiro, Fundação Getulio Vargas, October/December.

Sargent, T.J. and N. Wallace (1981): Some unpleasant monetarist arithmetic, Quarterly Review, vol. 5, No. 3, Minneapolis, Federal Reserve Bank of Minneapolis. 
Skidmore, T.E. (1988): The Politics of Military Rule in Brazil, 1964-85, New York, Oxford University Press.

Tanner, E. (1995): Intertemporal solvency and indexed debt in Brazil: evidence from 1976-1991, Journal of International Money and Finance, vol. 14, No. 4, Amsterdam, Elsevier Science, August.

Velloso, R. (1997): Uma proposta para acelerar o ajuste fiscal, in J.P. dos Reis Velloso (ed.), Brasil: desafios de um pais em transformação, Rio de Janeiro, Jose Olympio Editora.
Werneck, R.L.F. and A.S. Bevilaqua (1998): The Quality of the Federal Net Debt in Brazil, Texto para discussão, No. 385, Rio de Janeiro, Pontificia Universidade Catolica, April.

Wilcox, D.W. (1989): The sustainability of government deficits: implications of the present-value borrowing constraint, Journal of Money, Credit, and Banking, vol. 21, No. 3, Ohio, Ohio State University Press, August. 